\title{
Effect of Ethanol Extract of Chayote (Sechiumedule.Jacq.Swartz) on the Activity of Glutathione Peroxide (GPx) in House Mice (Musmusculus L) Strain DD Webster Hyperglycemia Induced by Streptozotocin (STZ)
}

\author{
Jekson Martiar Siahaan'), Urip Harahap ${ }^{2)}$, RickeLoesnihari3) \\ 1) Biomedical Science, Faculty of Medicine, North Sumatera University \\ 2) Faculty of Pharmacy, North Sumatera University \\ 3) Faculty of Medicine, North Sumatera University
}

\begin{abstract}
Background: Streptozotocin can cause hyperglycemia in guinea pig through the mechanism of oxidative stress which damages pancreatic $\beta$ cells. Ethanol extract of chayote can decrease oxidative stress. This study aimed to determine the effect of Ethanol Extract of Chayote ((EEBLS) Ekstrak Etanol Buah Labu Siam) on decreasing blood sugar content and increasing the activity of glutathione peroxide enzyme.

Subjects and Method: This was an experimental study. The samples were using random sampling technique. The control group was using male white mice (Musmusculus L.) Strain DD Webster which randomized into four groups: negative control group, positive control group, group which got EEBLS of $100 \mathrm{mg} / \mathrm{kgBB}$, and group which got EEBLS of $200 \mathrm{mg} / \mathrm{kgBB}$.

Results: The result of the research showed that there was significant decrease in blood sugar, compared with the control group. There was insignificant decrease in the activity of glutathione peroxide enzyme, compared with the control group.

Conclusion: The conclusion of the research was that EEBLS of $200 \mathrm{mg} / \mathrm{kgBB}$ decreased blood sugar content of mice significantly, but there was no significant change in the activity of glutathione peroxide enzyme when EEBLS was given to the mice.
\end{abstract}

Keywords: streptozotocin, oxidative stress, antioxidant, flavonoid

Correspondence:

Jekson Martiar Siahaan. Biomedical Science, Faculty of Medicine, North Sumatera University.

\section{BACKGROUND}

Diabetes Mellitus (DM) is a group of metabolic disease with hyperglycemia characteristics as the result of insulin excretion disorder, the work of insulin, or both of them. Prolonged hyperglycemia is related to long term damage, dysfunction, and failure of various organs (American Diabetes Association, 2014).

Persistent hyperglycemia in DM patients will cause the increase in oxidative stress as the result of imbalance between free radical and natural antioxidant formed by body (Sheikhpour, 2013). Hyperglycemia in guinea pig can be induced by using streptozotocin (STZ).

STZ or deoxy-2- [3-(methyl-3-nitronitrosoureido)-D-glucopiranose] is obtained from Streptomyces achromogenes and structurally, it is nitrosourea derivative $(\mathrm{Nu}-$ groho, 2006; Srinivasan dan Ramarao, 2007). The mechanism of STZ is particularly mediated by the forming of free radical Reactive Oxygen Species (ROS) and Reactive Nitrogen Species (RNS) which cause the damage in pancreas $\beta$ cells (Srinivasan dan Ramarao, 2007). ROS includes superoxide $\left(\cdot \mathrm{O}_{2}-\right)$, hydroxide $(\cdot \mathrm{OH})$, peroxide $\left(\cdot \mathrm{RO}_{2}\right)$, hydroperoxide $\left(\cdot \mathrm{HRO}_{2}-\right)$, non-ra- 
dical hydrogen peroxide $\left(\mathrm{H}_{2} \mathrm{O}_{2}\right)$, and hydrochlorous acid (HOC1). RNS includes nitric oxide $(\cdot \mathrm{NO})$, nitrogen dioxide $\left(\cdot \mathrm{NO}_{2}\right)$, nonradical peroxynitrite (ONOO), nitrous oxide $\left(\mathrm{HNO}_{2}\right)$, and alkyl peroxynitrates (RONOO). Glutathione peroxide (GPx) enzyme is one of enzymatic antioxidant (Moussa, 2008; Johansen et al., 2005; Rahman, 2007). Compared with superoxide dismutase-1 (SOD-1) and superoxide dismutase-2 (SOD-2) contents and catalase, GPx content is still higher in islet pancreas cells so that the accurate protection for pancreas $\beta$ cells is GPx (Robertson dan Harmon, 2007). In animal cells, antioxidant enzyme which is prioritized for $\mathrm{H}_{2} \mathrm{O}_{2}$ detoxification is $\mathrm{GPx}$, while catalase has much lower affinity for $\mathrm{H}_{2} \mathrm{O}_{2}$, compared with GPx (Jurcovicet et al., 2008). Low GPx enzyme is caused by the disorder which is related to free radical (Judge et al., 2005). High activity of GPx enzyme is able to protect isle pancreas cells which are caused by glucose toxicity that appears through the process of oxidative stress (Tanaka et al., 2002). The increase in the activity of GPx enzyme in the pancreas of mice is caused by the mechanism of detoxification compensation of peroxide hydrogen. In this research, it is found that the activity of glutathione reductase (GR) and glutathione-S-transferase (GSt) does not change in the pancreas of diabetes mice which indicates that GR and GSt enzymes do not play a significant role in oxidative stress protection in pancreas beta cells (Erejuwa et al., 2010).

Antioxidant is molecule which can forestall cell damage caused by free radical by stabilizing it. It can be grouped based on its origin to become natural and synthetic antioxidant. The effectiveness of natural antioxidant is lower than that of synthetic antioxidant, but it is safer because it is not contaminated by other chemical substances and it is easy to obtain, while the use of
Butylated Hydroxy Toluena (BHT) is limited since it is carcinogenic (Rahman, 2007). The best natural antioxidant comes from fruit and vegetables (Dimitrios, 2006), and one of the sources of natural antioxidant is Chayote (Sechium edule jacq. Swartz) (Firdous, 2011). It has a lot of benefits. Many Indonesian people use it as vegetable besides food industry, and its pectin content can be used in pharmacy and cosmetics (Daryono, 2002). Besides that, its pectin content has the effect of anti-cholesterol, anti-colon cancer and DM (Agustini, 2006). Based on the study on phytochemical screening of ethanol extract and the analysis on KLT (thin layer chromategraphy) of chayote extract conducted by Marliana et al., (2005), it is found that it has alkaloid, saponin, kardenolin/ bufadienol, and flavonoid (Marliana et al., 2005). Besides that, EEBLS (ekstrak etanol buah labu siam) can also function as anti-proliferation (Inuguez, 2012), anti-epilepsy, depressant power of central nerve system (Firdous, 2012). The study on the effect EEBLS as an antidiabetes has also been conducted (Maity, 2013). Its extract water also has neuroprotective effect (Mumtaz et al., 2013). Chayote extract is useful as anti-microbe on bacteria and fungi in digestive tract. Its leaves and fruit have the effect of diuresis, cardio-protective, and anti-inflammation, and its leaves have been used as an antiarteriosclerosis, hypertension, and can dissolve kidney stones (Kamble et al., 2008; Gordon et al., 2000). Active substance in chayote can be extracted by using certain solution. Generally, solvent which is used to extract natural substances is ethanol because it is better than water (Lukiati, 2012). Ethanol extract in chayote is also used as hepatoprotector probably because of its antioxidant activity (Firdous et al., 2012). There are a lot of benefits of chayote; but unfortunately, not many people get scien- 
tific information related to antioxidant content and the benefits of chayote, especially for diseases caused by free radical. Besides that, previous researches still dealt with the effect of antioxidant on hyper in mice; therefore, the researcher is interested in analyzing the effect of EEBLS on the activity of glutathione peroxide in white male mice which hyperglycemia is induced by STZ.

\section{SUBJECTS AND METHOD}

This study used experimental. The samples were taken by using simple random sampling technique, using white male mice (Mus musculus L.) Strain DD Webster which was randomized into 4 groups: negative control group, positive control group STZ $60 \mathrm{mg} /$ $\mathrm{kgBB}$ ), group which got STZ $60 \mathrm{mg} / \mathrm{kgBB}$ and EEBLS of $100 \mathrm{mg} / \mathrm{kgBB}$, and group which got STZ $60 \mathrm{mg} / \mathrm{kgBB}$ and EEBLS of $200 \mathrm{mg} / \mathrm{kgBB}$. Mice (Mus musculus L.) strain DD Webster DM when, in the fourth day after STZ is given, blood glucose content is $>250 \mathrm{mg} / \mathrm{dl}$. When blood sugar content increases, EEBLS is given until the $28^{\text {th }}$ day.

\section{RESULTS}

The guinea pig used in this research is healthy mice with their normal blood sugar content.

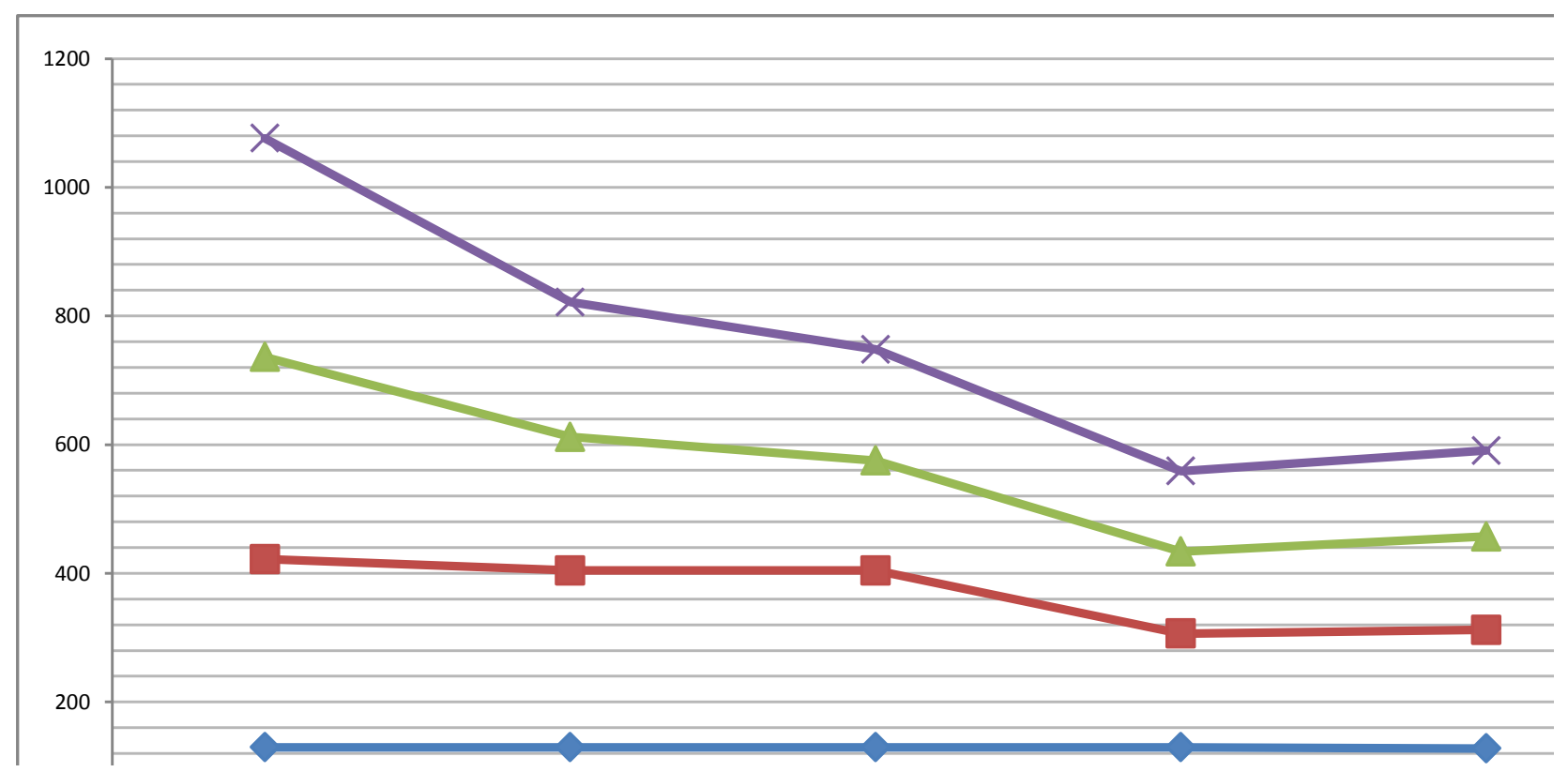

Picture 1 KGD per week

Explanation: P1 Negative control (mg/dl), P2 Positive control (mg/dl), P3 EEBLS $100 \mathrm{mg}$ (mg/dl), P4 EEBLS $200 \mathrm{mg}(\mathrm{mg} / \mathrm{dl})$

Glucometer is used for KGD measurement in order to make sure that the mice are normal. The result of KGD has been observed until the 28 day of the experiment as seen in Picture 1.
From the result of the study, it is found that the data of measuring the activity of peroxide glutathione enzyme from the blood of white male mice is found after the treatment within 28 days, as it is seen in Table 1. 
Table 1. The result of the activity of peroxide glutathione of white male mice after the treatment within 28 days

\begin{tabular}{cccccc}
\hline & \multicolumn{5}{c}{ Enzyme Outcome } \\
\cline { 2 - 5 } Group & \multirow{2}{*}{ Mean } & SD & \multicolumn{3}{c}{ 95\% CI } \\
\cline { 3 - 5 } & 420.04 & 78.95 & 337.19 & 502.90 \\
P1 & 425.98 & 22.50 & 405.17 & 446.79 & \\
P2 & 427.57 & 73.82 & 350.11 & 505.04 & \\
P3 & 418.46 & 54.90 & 360.85 & 476.08 \\
P4 & & & & \\
\hline
\end{tabular}

Information:

P1 Negative control (mg/dl)

P2 Positive control (mg/dl)

P3 EEBLS $100 \mathrm{mg}(\mathrm{mg} / \mathrm{dl})$

P4 EEBLS $200 \mathrm{mg}(\mathrm{mg} / \mathrm{dl})$

\section{DISCUSSION}

Based on Picture 1 above, it is found that STZ damages pancreas $\beta$ cells so that KGD increases. KGD groups of $\mathrm{P}_{2}, \mathrm{P}_{3}$, and $\mathrm{P}_{4}$ which have been induced by STZ is higher than that of P1 group. There is the decrease in KGD in $\mathrm{P} 2$ group starting from the $21^{\text {st }}$ day while the decrease in KGPD in $\mathrm{P}_{3}$ and $\mathrm{P} 4$ groups has been known has been known in the $7^{\text {th }}$ day. The group which gets the dosage of $200 \mathrm{mg}$ undergoes the lowest decrease in KGD which is in line with the result of the research conducted by Maity et al., (2013). The decrease in KGD in the treatment group is caused by giving EEBLS which contains flavonoid (Siciliano et al., 2004; Marliana et al., 2005). Flavonoid is anti-diabetes by disturbing glucose absorption in intestines, improving glucose tolerance, disturbing carbohydrate metabolism through enzyme obstruction $\alpha$ amylase and enzyme a glucosidase, stimulating glucose excretion in peripheral tissues; besides that, flavonoid also stimulates insulin secretagogues and acts like insulin in stimulating glycogen synthesis (insulin mimetics) (Brahmachari, 2011; Piparo, 2008; Sahgal et al., 2010). The decrease in KGD in P2 group can occur because of self-recovery by the body through the improvement of pancreas $\beta$ cells and new cell spliting (mitosis) gradually. The decrease in the number of pancreas $\beta$ cells in hyperglycemia animals is known in the $7^{\text {th }}$ day and continuously decreases until the $28^{\text {th }}$ day (Erwin et al., 2012). The decrease in KGD in $\mathrm{P}_{3}$ and $\mathrm{P}_{4}$ groups begins to be known after EEBLS is given in the $7^{\text {th }}$ day and begins to be normal in the $28^{\text {th }}$ day. This indicates that the decrease in KGD in $\mathrm{P}_{3}$ and $\mathrm{P}_{4}$ groups is due to the influence of flavonoid in EEBLS, while the improvement of pancreas $\beta$ cells is indicated by the improvement of KGD in the mice.

The study shows significant difference in the activity of enzyme glutathione peroxide in the white male mice. The lowest activity of glutathione peroxide enzyme is found in the treatment 4 group which indicates that oxidative stress in $\mathrm{P}_{4}$ group is lower than that in the $\mathrm{P} 1$ negative control group which can be seen from the enzyme activity in $\mathrm{P}_{4}$ group which is lower than those in $\mathrm{P}_{1}, \mathrm{P}_{2}$, and $\mathrm{P}_{3}$ groups. The decrease in the activity of glutathione peroxide enzyme is in line with the result of the research conducted by Bhatt et al, (2011). C-glycosyl in methanol Enicostem malitto- 
rsle Blume extracts decreases the activity of GPx in nephrotoxic mice that are induced by gentamicin (Bhatt et al., 2011). The result of the study conducted by Gargari et al., in which extract of the grape nuts which contains proantisionism can decrease the activity of GPx although the decrease is not significant (Pourhassem et al., 2011)

EEBLS $200 \mathrm{mg} / \mathrm{kg}$ BB can significantly decrease blood glucose content of mice and there is no significant change in the activity of glutathione peroxide with giving EEBLS.

\section{REFERENCE}

Agustini K, Marlina S (2006). Effect of length of administration sechiumedule extract on decreasing blood cholesterol in male albino rats. Jurnal Bahan Alam Indonesia.

American Diabetes Association (2014). Diagnosis and classification of diabetes mellitus. Diabetes Care 37(1): 81-90.

Bhatt NM, Chauhan K, Gupta S, Pillai P, Pandya C, Thaikoottathil J V (2011). Protective effect of enicostemma littorale blume methanolic extract on gentamicin-induced nephrotoxicity in rats. Department of Biochemistry, Faculty of Science, Johns Hopkins University, School of Medicine 720 Rutland Ave, 1054 Ross Bldg Baltimore MD (4):83-90.

Brahmachari, Goutam (2011). Bioflavonoids with promising anti-diabetic potentials: A critical survey. Research signpost 6619370:187-212.

Cadena-iñiguez J, Soto-hernández M, Torres-salas A, Aguiñiga- I, Ruiz-posadas L (2013) The antiproliferative effect of chayote varieties (Sechium edule Jacq.on tumour cell lines) 7(8):45560.
Daryono, Elvianto (2002). Ekstraksi pektin dari labu siam. Jurnal Teknik Kimia. 7 (1).

Dimitrios B (2006). Sources of natural phenolic antioxidants. Trends Food Sci Technol 17(9):505-12.

Erejuwa OO, Sulaiman SA, Wahab MS, Sirajudeen KNS, Salleh MSM, Gurtu S (2010). Antioxidant protection of Malaysian tualang honey in pancreas of normal and streptozotocin-induced diabetic rats. Ann Endocrinol (Paris) [Internet]. Elsevier Masson SAS 71 (4): 291-6.

Erwin, Etriwati, Rusli (2012). Mencit (Mus musculus) galur balb-c yang diinduksikan streptozotosin berulang sebagai hewan model DM. Jurnal Kedokteran Hewan 6(1).

Firdous SM, Ahmed S, Dey S (2012). Antiepileptic and central nervous system depressant activity of Sechium edule fruit extract. Bangladesh J Pharmacol 7(3):199-202.

Firdous MSM, Paul S, Bag AK (2013). Effect of sechium edule on chemical induced kidney damage in experimental animals. Bangladesh $\mathrm{J}$ Pharmacol 8 (1): 28-35.

Gordon EA, Guppy LJ, Nelson M (2000). The antihypertensive effects of the Jamaican Cho-Cho (Sechium edule). West Indian Medical Journal: 27-31.

Johansen JS, Harris AK, Rychly DJ, Ergul A (2005). Oxidative stress and the use of antioxidants in diabetes: linking basic science to clinical practice. Cardiovasc Diabetol 4(1): 5 .

Judge S, Jang YM, Smith A, Hagen T, Leeuwenburgh C (2005). Age-associated increases in oxidative stress and antioxidant enzyme activities in cardiac interfibrillar mitochondria: implica- 
tions for the mitochondrial theory of aging. FASEB J 19(3): 419-21.

Jurcovic, Simona, Josko O, Janja M (2008). Molecular Impact of Glutationperoksidase in antioxidant process. Biochemiamedica 18(2):162-74

Kamble MB, Dumbre RK, Rangari VD (2008). Hepatoprotective activity studies of herbal formulations. Int $\mathrm{J}$ Green Pharm 2: 147-51.

Lukiati B (2012). Profil distribusi inos dan kadar no pankreas tikus diabetes melitus hasil induksi mld-stz pasca pemberian ekstrak etanol temugiring 6(2).

Maity S, Firdous SM, Debnath R (2013). Evaluation of antidiabetic activity of ethanolic extract of Sechium edule fruits in alloxan-induced diabetic rats. World J Pharm Pharm Sci 2(5): 3612-21.

Marliana SD, Suryanti V (2005). Skrining fitokimia dan analisis kromatografi lapis tipis komponen kimia buah labu siam (Sechium edule Jacq . Swartz .) dalam Ekstrak Etanol. Biofarmasi 3(1):26-31.

Moussa SA (2008). Oxidative stress in diabetes mellitus. Rom J Biophys 18(3): $225-36$.

Nugroho AE (2006). Animal models of diabetes mellitus : Pathology and mechanism of some diabetogenics. Biodiversitas, J Biol Divers 7(4):378-82.

Piparo Elo, Scheib H, Frei N, Williamson G, Grigorov M, Chou CJ (2008). Flavonoids for controlling starch digestion : structural requirements for inhibiting human r-amylase 3555-61.

Pourghassem-gargari B, Abedini S, Babaei $\mathrm{H}$, Aliasgarzadeh A (2011). Effect of supplementation with grape seed (Vitis vinifera) extract on antioxidant status and lipid peroxidation in pati- ent with type II diabetes. Journal of Medicinal Plants Research: 2029-34.

Rahman K (2007). Studies on free radicals, antioxidants, and co-factors. Clin Interv Aging 2(2):219-36.

Robertson RP, Harmon JS (2007). Pancreaticislet $\beta$-cell and oxidative stress: The importance of glutathione peroxidase. FEBS Lett 581(19): 3743-8.

Sahgal G, Ramanathan S, Sasidharan S, Mordi MN, Ismail S, Mansor SM (2010). Brine shrimp lethality and acute oral toxicity studies on Swietenia mahagoni (Linn.) Jacq. seed methanolic extract. Pharmacognosy research: 215-20.

Sheikhpour R (2013). Diabetes and oxidative stress: The mechanism and action. Iran J diabtes Obes 5(1).

Siciliano T, De Tommasi N, Morelli I, Braca A (2004). Study of flavonoids of Sechium edule (Jacq) Swartz (Curcubitaceae) different edible organs by liquid chromatography photodiode array mass spectrometry. Journal of Agricultural and Food Chemistry: 6510-6515.

Srinivasan K, Ramarao P (2007). Animal models in type 2 diabetes research: an overview. Indian J Med Res 125(3): 451-72.

Tanaka Y, Tran P, Harmon J, Robertson RP (2002). A role for glutathione peroxidase in protecting pancreatic beta cells against oxidative stress in a model of glucose toxicity. Proc Natl Acad Sci USA 99(19): 12363-12368. 